\title{
Selenium improves the transport dynamics and energy conservation of the photosynthetic apparatus of in vitro grown Billbergia zebrina (Bromeliaceae)
}

\author{
A.F.C. SOUZA, J.P.R. MARTINS ${ }^{+}$, A.B.P.L. GONTIJO, and A.R. FALQUETO \\ Department of Agrarian and Biological Sciences, Federal University of Espirito Santo, Litorâneo, \\ 29932-540 São Mateus, ES, Brazil
}

\begin{abstract}
Despite having beneficial effects, selenium is not an essential element for plants and its action mechanisms are still unclear. In this context, we evaluated effects of selenium, considering possible modulations of the photosynthetic apparatus of Billbergia zebrina plants during in vitro culture. Lateral shoots of B. zebrina were grown in a medium with different concentrations of selenium $(0,2,4$, and $16 \mu \mathrm{M})$. After $75 \mathrm{~d}$, concentrations of photosynthetic pigments, growth traits, and chlorophyll $a$ fluorescence were evaluated. In low concentrations, selenium increased the potential energy conservation capacity of the photosynthetic apparatus, maintained the PSII energy transport reaction stability, and improved the electron transport dynamics between the intersystem and PSI. In addition, B. zebrina showed physiological disturbances at Se concentrations equal or greater than $16 \mu \mathrm{M}$, presenting reduced growth and photosynthetic pigment contents and impaired photosynthetic apparatus.
\end{abstract}

Additional key words: bromeliad; electron transport flux; fluorescence transient; JIP test; performance index; reaction center.

\section{Introduction}

Selenium $(\mathrm{Se})$ is a nonessential element to plants. However, Se is known to have a beneficial effect when present in low concentrations (Pilon-Smith et al. 2009). Several studies have demonstrated multiple impacts of Se on plant physiology, such as increased biomass production (Chen et al. 2014, Jiang et al. 2015, Feng et al. 2016), delayed senescence (Xue et al. 2001), increased tolerance to oxidative damage (Feng et al. 2013, Diao et al. 2014, Qing et al. 2015, Tang et al. 2015), increased production of carotenoid pigments (Ning et al. 2016), higher tolerance to photooxidative stresses (Seppänen et al. 2003), greater carbohydrate accumulation (Turakainen et al. 2006, Owusu-Sekyere et al. 2013), and alleviation of the effects of biotic and abiotic stresses (Hanson et al. 2003, Yao et al.
2010, Hasanuzzaman and Fujita 2011, Han et al. 2015).

Plants vary substantially in their physiological responses to Se (Terry et al. 2000) and little is known about the possible mechanisms of action (Feng and Wei 2012). In this context, physiological increments caused by Se in plants can be attributed to several different mechanisms, such as reduced production of ROS, increased production of enzymatic and nonenzymatic antioxidants, recovery of damaged chloroplasts, and higher production of vital metabolites (Bachiega et al. 2016, Tian et al. 2016). The deficiency and toxicity of Se have been recorded worldwide, depending on its availability in the environment (Zhang et al. 2007). From the ecotoxicological standpoint, there is a narrow concentration range from which an element goes from beneficial to toxic (Pilon-Smits and LeDuc 2009, Zhu et al. 2009). Even low contamination, if present

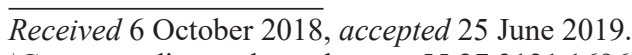

${ }^{+}$Corresponding author; phone: +55 273121 1696, e-mail: jprmartinss@yahoo.com.br

Abbreviations: $\mathrm{ABS} / \mathrm{RC}$ - absorption flux per $\mathrm{RC} ; \mathrm{Chl}$ - chlorophyll; $\mathrm{Ch}_{\mathrm{total}}-$ total chlorophyll; $\mathrm{DI}_{0} / \mathrm{RC}$ - dissipated energy flux per $\mathrm{RC}$; $\mathrm{ET}_{0} / \mathrm{RC}$ - electron transport flux per RC; $\mathrm{F}_{0}$ - minimal fluorescence yield of the dark-adapted state; $\mathrm{F}_{\mathrm{I}}$ - fluorescence intensity at $30 \mathrm{~ms}$; $\mathrm{F}_{\mathrm{J}}$ - fluorescence intensity at $2 \mathrm{~ms} ; \mathrm{F}_{\mathrm{K}}$ - fluorescence intensity at $0.3 \mathrm{~ms} ; \mathrm{F}_{\mathrm{m}}$ - maximal fluorescence yield of the dark-adapted state; FM - fresh mass; $F_{P}$ - fluorescence intensity at $300 \mathrm{~ms}$; OCE - oxygen-evolving complex; Pheo - pheophytin; $\mathrm{PI}_{(\mathrm{ABS})}-$ performance index based on absorption; $\mathrm{PI}_{\text {(Total) }}$ - overall performance index, which measures the performance up until the final electron acceptors of PSI; RC - reaction center; RC/ABS - total number of active reaction center per absorption; $\mathrm{RE}_{0} / \mathrm{RC}$ - reduction of end acceptors at PSI electron acceptor side per RC; ROS - reactive oxygen species; $\mathrm{TR}_{0} / \mathrm{RC}$ - trapping flux per $\mathrm{RC} ; \mathrm{V}_{\mathrm{I}}-$ relative variable fluorescence at $30 \mathrm{~ms}$ (point I); $\mathrm{V}_{\mathrm{J}}$ - relative variable fluorescence at $2 \mathrm{~ms}$ (point $\mathrm{J}$ ); $\delta \mathrm{R}_{0}$ - efficiency/probability with which an electron from the intersystem electron carriers moves to reduce end electron acceptors at the PSI acceptor side; $\varphi \mathrm{D}_{0}$ - quantum yield of energy dissipation; $\varphi \mathrm{E}_{0}$ - quantum yield of electron transport; $\varphi \mathrm{P}_{0}$ - maximum quantum yield of primary photochemistry; $\varphi \mathrm{R}_{0}-$ quantum yield of reduction of end electron acceptors at the PSI acceptor side; $\rho \mathrm{R}_{0}$ - efficiency with which a trapped exciton can move an electron into the electron transport chain from $\mathrm{Q}_{\mathrm{A}}^{-}$to the PSI end electron acceptors; $\psi \mathrm{E}_{0}$ - probability that a trapped exciton moves an electron into the electron transport chain beyond $\mathrm{Q}_{\mathrm{A}}^{-}$.

Acknowledgments: The authors would like to acknowledge the scholarship awarded by the CNPq (Brazilian National Council for Scientific and Technological Development) and the FAPES (Espírito Santo State Research Foundation). 
at a sufficiently large scale, can cause environmental damages (Lindblom et al. 2013). Hence, environmental contamination by Se can have an impact on human health, agricultural yield, and the stability of natural ecosystems.

High concentrations of Se can damage the photosynthetic apparatus, inhibit photosynthesis, and reduce starch production (Vítová et al. 2011, Łabanowska et al. 2012, Wang et al. 2012). However, in adequate concentrations, Se can enhance photosynthesis and protect the PSII (Feng et al. 2015, Jiang et al. 2015). Previous studies have shown that chlorophyll (Chl) $a$ fluorescence analysis is an efficient nondestructive technique to evaluate modulations in the photosynthetic apparatus under different environmental conditions (Zushi et al. 2017). In the present study, the bromeliad, Billbergia zebrina (Herbert) Lindley, was chosen for in vitro cultivation. Analyses using in vitro cultures are advantageous since they allow isolating the effects of a particular substance on the plant metabolism in relation to all other potential stressing agents (Martins et al. 2016). Within this framework, the aim of this study was to evaluate the effect of Se on the photosynthetic performance of in vitro grown B. zebrina (Bromeliaceae), considering possible modulations (improvement, damage and/or changed site of action) in the photosynthetic apparatus, contributing to a better understanding of Se action in plants.

\section{Materials and methods}

Exposure of plant material to Se during in vitro growth: Lateral shoots of $B$. zebrina, obtained from plants previously established in vitro, were selected using a scalpel and transferred to 268-ml glass jars containing $50 \mathrm{ml}$ of Murashige and Skoog plant growth medium (Murashige and Skoog 1962) supplemented with $30 \mathrm{~g}$ $\mathrm{L}^{-1}$ sucrose and solidified with $3.5 \mathrm{~g} \mathrm{~L}^{-1}$ agar. Selenium was added to the medium in exponential scale with the following concentrations: $0,2,4$, and $16 \mu \mathrm{M}$. Sodium selenite $\left(\mathrm{Na}_{2} \mathrm{SeO}_{3}\right)$ was used as a source of Se, considering the molecular mass of Se in all concentration calculations. The medium $\mathrm{pH}$ was adjusted to 5.8 before autoclaving at $120^{\circ} \mathrm{C}$ for $20 \mathrm{~min}$. After inoculation under a laminar flow hood, the material was kept in a growth room for $75 \mathrm{~d}$ at $25 \pm 2^{\circ} \mathrm{C}$ and a photoperiod of $16-\mathrm{h}$ light/8-h dark.

Growth analysis: To evaluate the in vitro growth, 50 plants were randomly sampled from each treatment, divided into 10 parcels, and weighed on an analytical scale. The fresh mass (FM) of roots and aerial parts of the samples were determined separately.

Photosynthetic pigments content: To quantify the photosynthetic pigments, $0.03 \mathrm{~g}$ of plant material was extracted from the third completely expanded leaf in the central rosette region of 12 randomly selected samples. The plant material was placed in test tubes containing $5 \mathrm{ml}$ of $80 \%$ acetone and kept in the dark at $4^{\circ} \mathrm{C}$ for $48 \mathrm{~h}$, before spectrophotometric analysis. Readings were performed using a GENESYSTM $10 S$ UV-Vis spectrophotometer (Thermo Fisher Scientific, West Palm Beach, FL, USA) at 645 and $665 \mathrm{~nm}$ for $\mathrm{Chl} a$ and $\mathrm{Chl} b$, respectively. The contents of photosynthetic pigments, expressed in $\mathrm{mg} \mathrm{g}^{-1}(\mathrm{FM})$, were calculated according to the equations of Arnon (1949) and Lichtenthaler (1987), as follows: Chl $a=\left[\left(12.7 \times \mathrm{A}_{663}\right) \times\left(2.69 \times \mathrm{A}_{645}\right) /(1000 \times \mathrm{FM}) \times \mathrm{V}\right]$, Chl $b=\left[\left(22.9 \times \mathrm{A}_{645}\right) \times\left(4.68 \times \mathrm{A}_{663}\right) /(1000 \times \mathrm{FM}) \times \mathrm{V}\right]$, and $\mathrm{Chl}_{\text {total }}=\left[\left(20.2 \times \mathrm{A}_{663}\right) \times\left(2.69 \times \mathrm{A}_{645}\right) /(1000 \times \mathrm{FM}) \times \mathrm{V}\right]$, where $\mathrm{V}=$ volume of the acetone extract in $\mathrm{cm}^{3}$ and $\mathrm{A}=$ absorbance at the specified wavelength ( $\mathrm{nm})$, measured with a 1-cm cuvette.

Chl $\boldsymbol{a}$ fluorescence analysis: The Chl $a$ fluorescence transient was measured after $75 \mathrm{~d}$ of cultivation. Measurements were performed in 15 plant samples per treatment, always in the third fully expanded leaf departing from the rosette's center. Leaves were previously adapted to the dark for 30 min using a leaf clips (Hansatech) to assure complete oxidation of the photosynthetic system. The transients were induced with $1 \mathrm{~s}$ of incident light for a saturating light pulse with maximum intensity of $3,000 \mu \mathrm{mol}$ (photon) $\mathrm{m}^{-2} \mathrm{~s}^{-1}$ in a leaf area of $4 \mathrm{~mm}$ in diameter using a portable fluorometer (Handy PEA, Hansatech Instruments Ltd., King's Lynn, Norfolk, UK). Emission of the transient fluorescence was then registered from $10 \mathrm{~ms}$ to $1 \mathrm{~s}$ with 120 fluorescence points. From the fluorescence transient curve OJIP, the JIP test was evaluated according to the theory of energy flow across biomembranes (Strasser and Strasser 1995, Strasser et al. 2004) considering the parameters cited in Appendix.

Statistical analysis: Experiments were performed in a completely randomized design. The parameters of the JIP test, photosynthetic pigments, and fresh mass (FM), were submitted to analysis of variance (ANOVA) and the means were compared using Scott-Knott's test at 5\% significance. Analyses were performed using the software SISVAR.

\section{Results}

Significant reductions were observed in the FM of both roots and aerial parts of the plants treated with $16 \mu \mathrm{M} \mathrm{Se}$,

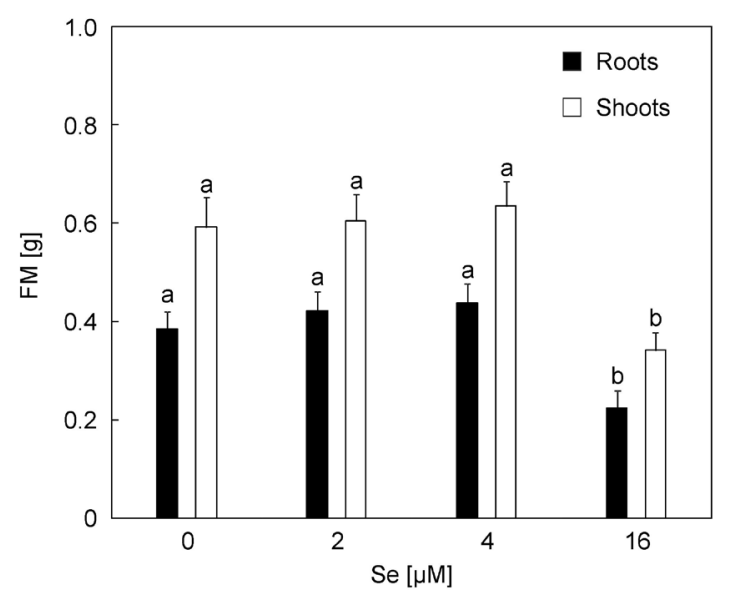

Fig. 1. Growth traits of in vitro grown Billbergia zebrina plants as a function of Se concentrations $(0,2,4$, and $16 \mu \mathrm{M})$. For each growth trait, means $\pm \mathrm{SD}(n=10)$ followed by the same letter are not significantly different according to the Scott-Knott's test $(p<0.05)$. FM - fresh mass. 
without significant effects of the other treatments (Fig. 1). Similarly, the concentration of Chl $a$ and $\mathrm{Chl}_{\text {total }}$ decreased under $16 \mu \mathrm{M}$ Se without any alteration in the concentration of $\mathrm{Chl} b$ among the Se concentrations (Table 1). Samples of $B$. zebrina, when submitted to treatments of Se in vitro, remained photosynthetically active and the curves had a typical OJIP polyphasic increase (Fig. $2 A$ ). Relative to the control, there was a decrease in $\mathrm{F}_{0}$ and of the obtained fluorescence at $0.3 \mathrm{~ms}\left(\mathrm{~F}_{\mathrm{K}}\right)$ in the samples cultivated with 2 and $4 \mu \mathrm{M}$ Se. On the other hand, higher values of $\mathrm{F}_{0}$ and $\mathrm{F}_{\mathrm{K}}$ were obtained in plants grown with $16 \mu \mathrm{M}$ (Fig. $2 A$ ). Suppressions of the fluorescence signs obtained at $2 \mathrm{~ms}$ and $300 \mathrm{~ms}$ ( $\mathrm{F}_{\mathrm{J}}$ and $\mathrm{F}_{\mathrm{P}}$, respectively) occurred in all $\mathrm{Se}$ treatments, including point I (obtained at $30 \mathrm{~ms}$ ). However,

Table 1. Content of chlorophyll $a(\mathrm{Chl} a)$, chlorophyll $b(\mathrm{Chl} b)$, and total chlorophyll $\left(\mathrm{Chl}_{\text {total }}\right)$ of in vitro grown Billbergia zebrina plants as a function of Se concentrations $(0,2,4$, and $16 \mu \mathrm{M})$. For each pigment, means $\pm \operatorname{SD}(n=12)$ followed by the same letter in the column are not significantly different according to Scott-Knott's $(p<0.05)$. FM - fresh mass.

\begin{tabular}{llll}
\hline Se $[\mu \mathrm{M}]$ & Chl $a\left[\mathrm{mg} \mathrm{g}^{-1}(\mathrm{FM})\right]$ & $\mathrm{Chl} b\left[\mathrm{mg} \mathrm{g}^{-1}(\mathrm{FM})\right]$ & $\mathrm{Chl}_{\text {total }}\left[\mathrm{mg} \mathrm{g}^{-1}(\mathrm{FM})\right]$ \\
\hline 0 & $1.11 \pm 0.06^{\mathrm{a}}$ & $0.42 \pm 0.04^{\mathrm{a}}$ & $1.83 \pm 0.10^{\mathrm{a}}$ \\
2 & $1.06 \pm 0.06^{\mathrm{a}}$ & $0.48 \pm 0.02^{\mathrm{a}}$ & $1.75 \pm 0.09^{\mathrm{a}}$ \\
4 & $1.09 \pm 0.03^{\mathrm{a}}$ & $0.44 \pm 0.01^{\mathrm{a}}$ & $1.79 \pm 0.05^{\mathrm{a}}$ \\
16 & $0.91 \pm 0.05^{\mathrm{b}}$ & $0.38 \pm 0.04^{\mathrm{a}}$ & $1.49 \pm 0.08^{\mathrm{b}}$ \\
\hline
\end{tabular}
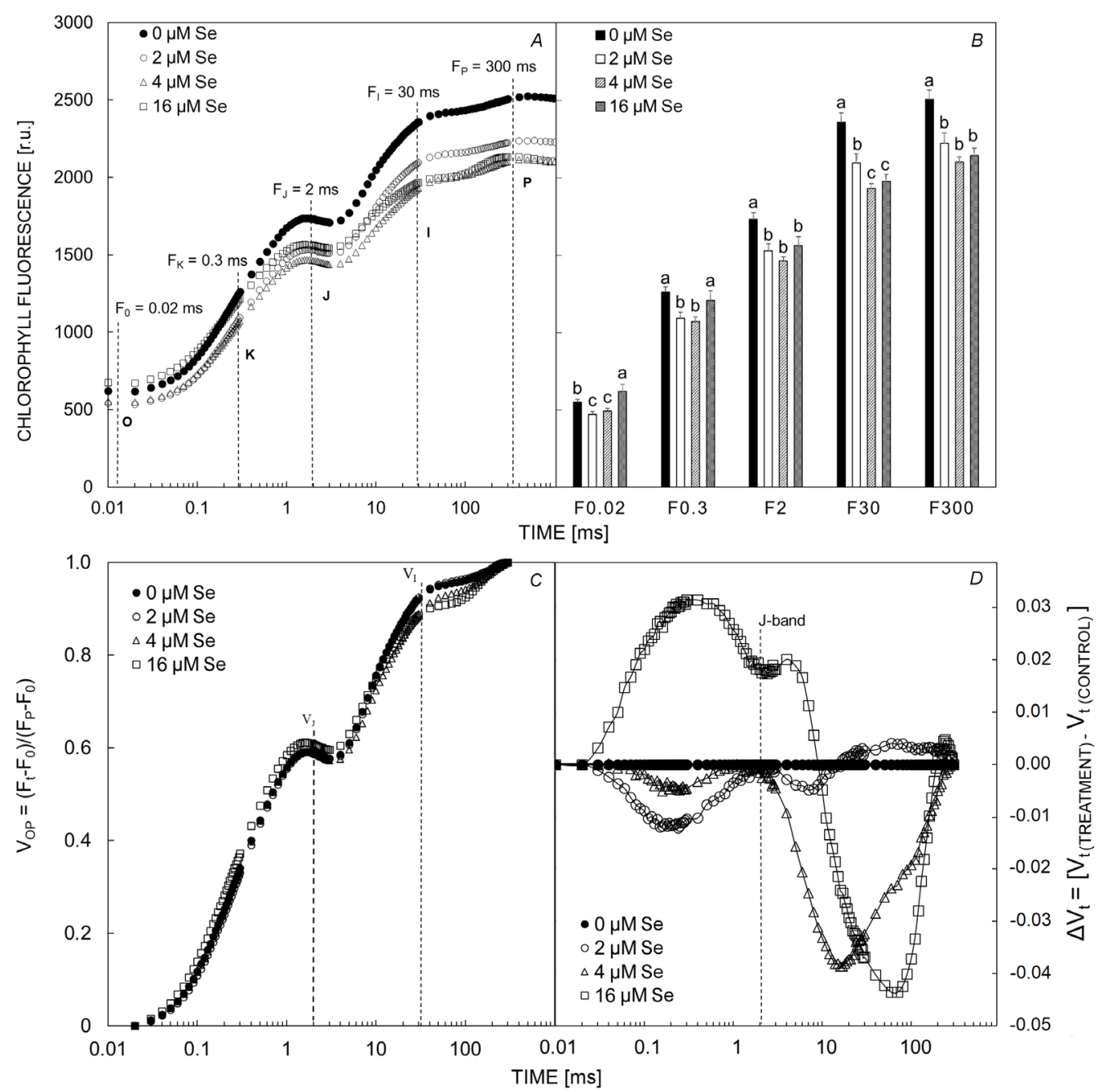

Fig. 2. Effects of different concentrations of selenium $(0,2,4$, and $16 \mu \mathrm{M})$ on the polyphase emission curve of chlorophyll $a$ fluorescence $(A)$; OJIP transient points $(\mathrm{O}=0.02 \mathrm{~ms}, \mathrm{~K}=0.3 \mathrm{~ms}, \mathrm{~J}=2 \mathrm{~ms}, \mathrm{I}=30 \mathrm{~ms}$, and $\mathrm{P}=300 \mathrm{~ms})(B)$; relative fluorescence between points 0.02 and $300 \mathrm{~ms}$ or $\mathrm{V}_{\mathrm{OP}}=\left(\mathrm{F}_{\mathrm{t}}-\mathrm{F}_{0}\right) /\left(\mathrm{F}_{\mathrm{m}}-\mathrm{F}_{0}\right)(C)$; and kinetic differences between $\mathrm{O}(0.02 \mathrm{~ms})$ and $\mathrm{P}(300 \mathrm{~ms})$ or $\Delta \mathrm{V}_{\mathrm{OP}}$ values established between 0.01 and $300 \mathrm{~ms}(D)$ in Billbergia zebrina plants grown in vitro. For each OJIP transient point, means $\pm \operatorname{SD}(n=15)$ followed by the same letter are not significantly different according to the Scott-Knott's test $(p<0.05)$. 
a higher suppression of point I was observed in the samples treated with $4 \mu \mathrm{M}$ and $16 \mu \mathrm{M}$ Se (Fig. $2 B$ ).

Increases in $\mathrm{V}_{\mathrm{J}}$ were observed in the samples treated with $16 \mu \mathrm{M}$ Se followed by suppression of $V_{I}$ in plants cultured with 4 and $16 \mu \mathrm{M}$ Se (Fig. $2 C$ ). Using the relative normalizations at $\Delta \mathrm{V}_{\mathrm{t}}$, established between 0.02 and $300 \mathrm{~ms}$, a positive deviation was observed in the samples cultivated with $16 \mu \mathrm{M}$ Se at $2 \mathrm{~ms}$, while for those treated with 2 and $4 \mu \mathrm{M}$ Se, no deviation was observed (Fig. 2D). However, in the phases included between points $\mathrm{J}$ and $\mathrm{P}$, negative differences were obtained at $30 \mathrm{~ms}$ (I-band) to the treatments with 4 and $16 \mu \mathrm{M}$ Se (Fig. 2D).

Negative differences were observed in the L-band and $\mathrm{K}$-band $\left(\Delta \mathrm{V}_{\mathrm{OK}}\right.$ and $\Delta \mathrm{V}_{\mathrm{OJ}}$ established between $0-0.3$ and $0-2 \mathrm{~ms}$, respectively) in the samples cultivated with 2 and $4 \mu \mathrm{M}$ Se, being more pronounced (higher negative amplitude) in those with lower concentrations (Fig. $3 A$ ). On the other hand, plants cultivated with $16 \mu \mathrm{M}$ Se showed positive differences in the L-band and K-band $(+0.026$ and +0.061 , respectively) compared to the control (Fig. 3).

The curves of higher amplitude observed to the relative fluorescence at $\mathrm{V}_{\mathrm{OI}} \geq 1.0$, obtained in the interval of 30 and $300 \mathrm{~ms}$, were observed for 4 and $16 \mu \mathrm{M} \mathrm{Se}$ (Fig. $4 A$ ), as well as taking longer to reach 0.5 in the $\mathrm{V}_{\text {IP }}$ coordinate established in the same time lapse, but considering $\mathrm{F}_{\mathrm{J}}$ and $F_{P}($ Fig. $4 B)$. The $\Delta V_{I P}=\left(F_{p}-F_{I}\right) /\left(F_{p}-F_{0}\right)$ increased gradually in plants cultivated with 4 and $16 \mu \mathrm{M} \mathrm{Se}$ (Fig. $4 B$ ). The curves regarding the relative fluorescence variable between points I-P or $\Delta \mathrm{V}_{\mathrm{IP}}=\left(\mathrm{V}_{\mathrm{IP}(\text { treatment })}-\mathrm{V}_{\mathrm{IP}(\text { (control) }}\right)$ were negative in relation to the control in the treatments with 4 and $16 \mu \mathrm{M}$ Se (Fig. 4C).

The specific energy fluxes extracted from the JIP test evidenced reductions in RC/ABS of plants grown with $16 \mu \mathrm{M}$ Se. Hence, the values of $\mathrm{ABS} / \mathrm{RC}$ were higher and differed significantly from the other treatments. Similarly, with $16 \mu \mathrm{M} \mathrm{Se}$, higher values of $\mathrm{TR}_{0} / \mathrm{RC}$ and $\mathrm{DI}_{0} / \mathrm{RC}$ were observed. No difference in $\mathrm{ET}_{0} / \mathrm{RC}$ was registered between the treatments, while $\mathrm{RE}_{0} / \mathrm{RC}$ increased significantly in the plants cultivated with 4 and $16 \mu \mathrm{M} \mathrm{Se}$ (Fig. 5).

The $\varphi \mathrm{P}_{0}=\mathrm{TR}_{0} / \mathrm{ABS}$ was higher and equivalent at 0,2 , and $4 \mu \mathrm{M} \mathrm{Se}$, differing from the treatments using $16 \mu \mathrm{M} \mathrm{Se}$. Therefore, with $16 \mu \mathrm{M}$ Se, higher values of $\varphi \mathrm{D}_{0}=\mathrm{DI}_{0} / \mathrm{ABS}$ were observed, since these are inversely proportional parameters (Fig. 6A). On the other hand, lower values of $\varphi \mathrm{E}_{0}=\mathrm{ET}_{0} / \mathrm{ABS}$ were observed in plants cultivated with $16 \mu \mathrm{M}$. For $\psi \mathrm{E}_{0}=\mathrm{ET}_{0} / \mathrm{TR}_{0}$, no differences were observed between the Se concentrations. Higher values of $\varphi R_{0}=$ $\mathrm{RE}_{0} / \mathrm{ABS}, \delta \mathrm{R}_{0}=\mathrm{RE}_{0} / \mathrm{ET}_{0}$, and $\rho \mathrm{R}_{0}=\mathrm{RE}_{0} / \mathrm{TR}_{0}$ were observed for the treatments with 4 and $16 \mu \mathrm{M} \mathrm{Se}$ (Fig. $6 A$ ). Higher values of $\mathrm{PI}_{(\mathrm{ABS})}$ were observed at 0,2 , and $4 \mu \mathrm{M}$ Se (Fig. $6 B$ ), differing from those obtained with $16 \mu \mathrm{M} \mathrm{Se}$. For $\mathrm{PI}_{(\text {Total })}$, the highest index observed was for $4 \mu \mathrm{M} \mathrm{Se}$ (Fig. 6C).

\section{Discussion}

The plants grown in the treatments with 0,2 , and $4 \mu \mathrm{M}$ Se did not show any difference in FM (Fig. 1). For alfalfa (Broyer et al. 1966), ryegrass (Hartikainen et al. 1997), and sorghum (Djanaguiraman et al. 2010), low concentrations of Se have also shown positive effects on plant growth. The capacity of Se to promote growth has been reported also in lettuce (Xue et al. 2001) and soybean (Djanaguiraman et al. 2005). In general, these studies have shown that the high concentrations of Se reduce growth, as observed in B. zebrina plants cultivated with $16 \mu \mathrm{M}$ Se (Fig. 1). According to Hartikainen et al. (2000) and Djanaguiraman et al. (2005), the effects of Se on plant growth can be attributed especially to the antioxidative function of Se, mediated by selenoproteins such as glutathione peroxidase. These compounds catalyze the reduction of hydroperoxidases with glutathione, protecting against oxidative damages (Stadtman et al. 1996, Kryukov et al. 2003).

The quantification of the photosynthetic pigments in plant tissues under different environmental conditions can be an important tool for ecophysiological evaluation

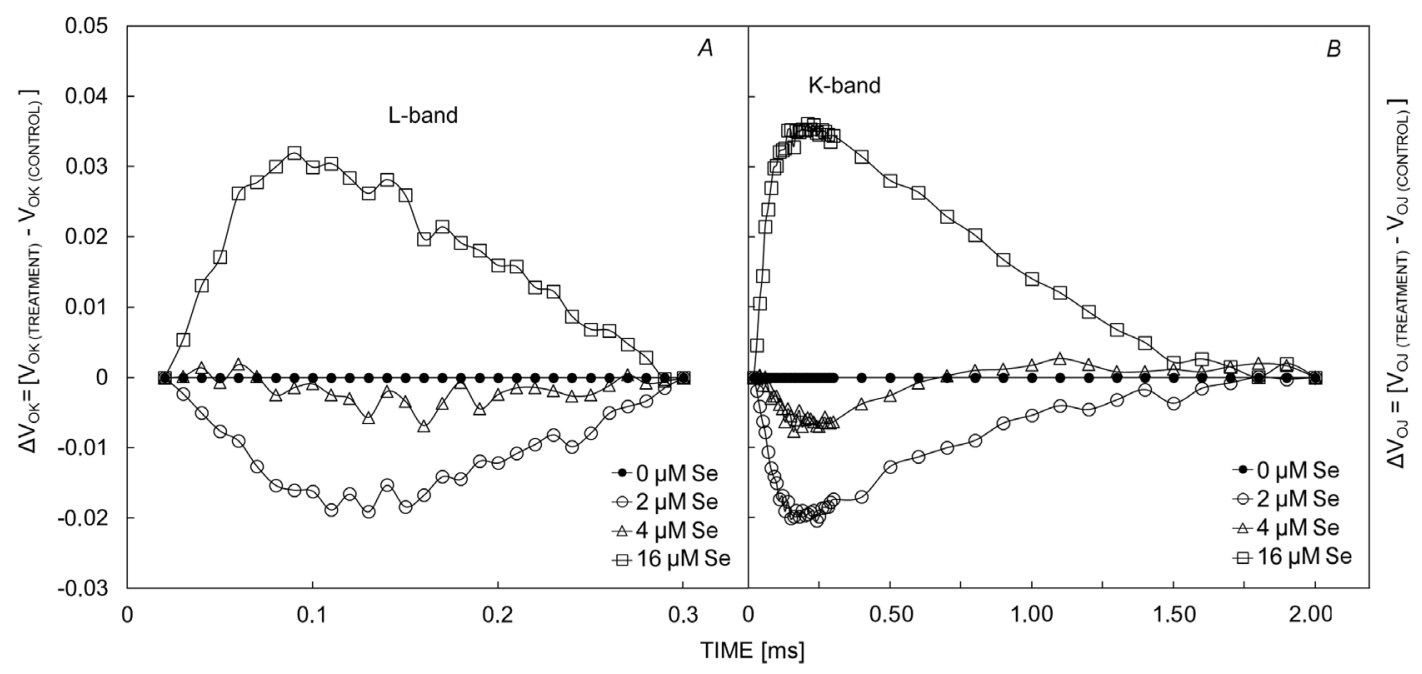

Fig. 3. Chlorophyll $a$ fluorescence transient points $(n=15)$ between the O-J and J-I stages of Billbergia zebrina plants grown in a medium with different Se concentrations. The kinetic differences between steps $\mathrm{O}$ and $\mathrm{K}$ showing the L-band $(A)$ and the kinetic differences between steps $\mathrm{O}$ and $\mathrm{J}$ showing the K-band $(B)$. 

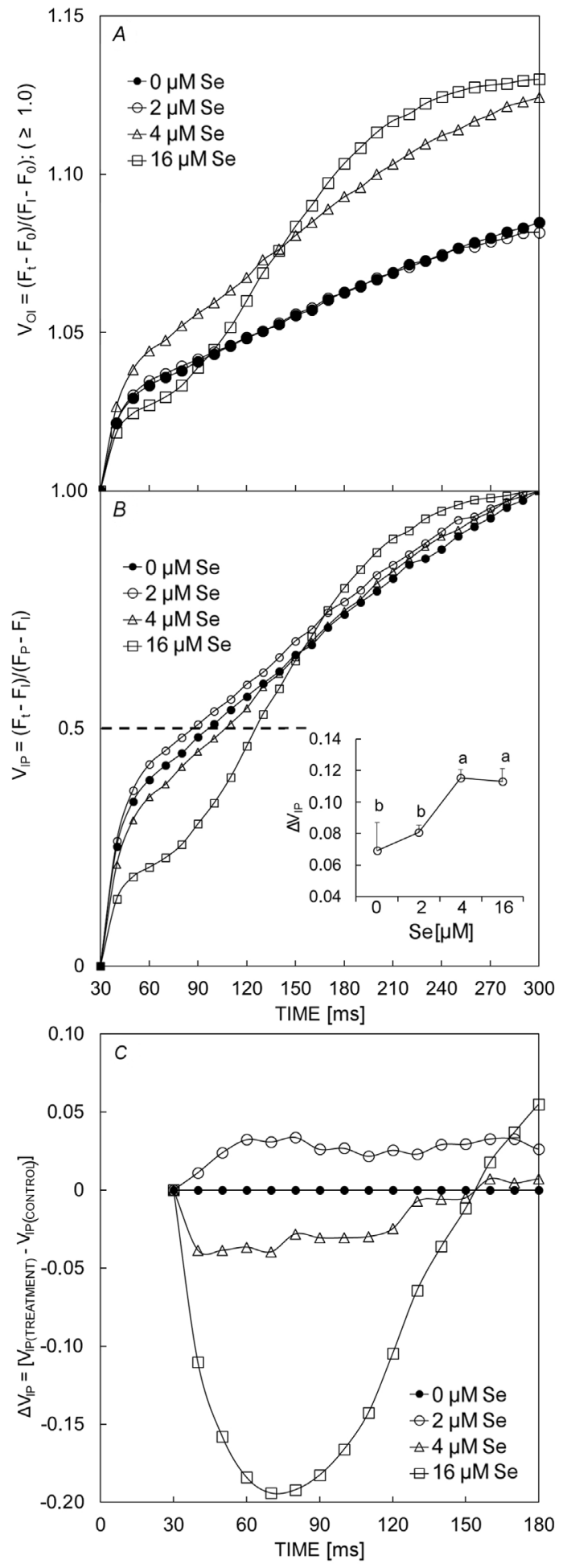

Fig. 4. Normalization between $\mathrm{F}_{0}$ and $\mathrm{F}_{\mathrm{I}}$ where $\mathrm{V}_{\mathrm{OI}}=\left(\mathrm{F}_{\mathrm{t}}-\mathrm{F}_{0}\right) /$ $\left(\mathrm{F}_{\mathrm{I}}-\mathrm{F}_{0}\right)$, where $\mathrm{V}_{\mathrm{OI}} \geq 1$ is in the range of 30 to $300 \mathrm{~ms}(A)$; normalization between $\mathrm{F}_{\mathrm{I}}$ and $\mathrm{F}_{\mathrm{P}}$ where $\mathrm{V}_{\mathrm{IP}}=\left(\mathrm{F}_{\mathrm{m}}-\mathrm{F}_{\mathrm{I}}\right) /\left(\mathrm{F}_{\mathrm{m}}-\mathrm{F}_{0}\right)(B)$; and relative variable fluorescence between the I-P points or $\Delta \mathrm{V}_{\mathrm{IP}}(C)$ in Billbergia zebrina plants grown in vitro with different concentrations of selenium $(0,2,4$, and $16 \mu \mathrm{M})$. Means \pm SD $(n=15)$ followed by the same letter, shown in the $\mathrm{V}_{\mathrm{IP}}$ chart, are not significantly different according to the Scott-Knott's test $(p<0.05)$.

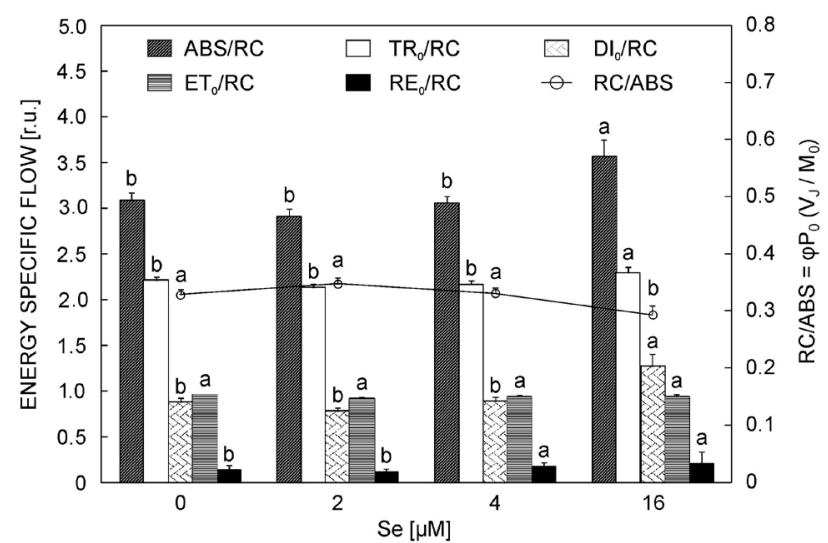

Fig. 5. Photochemical parameters derived from the analysis of the JIP test $[\mathrm{ABS} / \mathrm{RC}-$ absorption flux per reaction center $(\mathrm{RC})$; $\mathrm{DI}_{0} / \mathrm{RC}$ - dissipated energy flux per $\mathrm{RC} ; \mathrm{ET}_{0} / \mathrm{RC}$ - electron transport flux per RC; RC/ABS - total number of active reaction center per absorption; $\mathrm{RE}_{0} / \mathrm{RC}$ - reduction of end acceptors at PSI electron acceptor side per $\mathrm{RC} ; \mathrm{TR}_{0} / \mathrm{RC}$ - trapping flux per $\mathrm{RC}$ ] of in vitro grown Billbergia zebrina plants as a function of Se concentration $(0,2,4$, and $16 \mu \mathrm{M})$. For each JIP test parameter, means $\pm \mathrm{SD}(n=15)$ followed by the same letter are not significantly different according to the Scott-Knott's test $(p<0.05)$.

(Lambers et al. 2008). The photosynthetic pigments control the quantity of solar radiation that is absorbed by plants and other photosynthetic organisms. This makes the pigments intimately associated with the photosynthetic rates and the primary yield during the photosynthetic photochemical phase (Blackburn 2007).

Plants of B. zebrina cultivated with 2 and $4 \mu \mathrm{M} \mathrm{Se}$, although not varying in the contents of photosynthetic pigments (Table 1), showed modulations in the photosynthetic apparatus when compared to the control. Plants cultured with $16 \mu \mathrm{M}$ Se presented a decrease in the $\mathrm{Chl}_{\text {total }}$ content (Table 1). Therefore, these plants could undergo a photodestructive effect caused by the greater degradation rates and reduction in the biosynthesis of these pigments (Tausz et al. 2001), possibly related to the toxic effect of the high concentrations of Se (Zhong et al. 2015).

The increase in the magnitude of the fluorescence signals from the basal $\left(\mathrm{F}_{0}\right)$ to the maximum level $\left(\mathrm{F}_{\mathrm{m}}\right)$, with well-established intermediate points $\mathrm{J}$ and $\mathrm{I}$, indicated that the samples were photosynthetically active in all treatments (Mehta et al. 2010, Yusuf et al. 2010) (Fig. 2A). The suppression of all reference points of the OJIP transient $(0.02,0.3,2,30$, and $300 \mathrm{~ms})$ with 2 and $4 \mu \mathrm{M} \mathrm{Se}$ (Fig. 2B) likely indicate greater allocation of energy to photochemical quenching, given that there was no difference in terms of heat dissipation $\left(\mathrm{DI}_{0} / \mathrm{RC}\right)$ for these treatments (Fig. 5).

In the present study, the increase in $\mathrm{V}_{\mathrm{J}}$ observed in the plants cultivated with $16 \mu \mathrm{M}$ Se (Fig. 2C) suggests an accumulation of reduced quinone $\mathrm{A}\left(\mathrm{Q}_{\mathrm{A}}^{-}\right)$, which leads to deceleration in the electron transfer to the second acceptor of the electron transport chain, quinone $\mathrm{B}\left(\mathrm{Q}_{\mathrm{B}}\right)$ (Strasser et al. 2000, Chen et al. 2014). The kinetic difference $\left(\Delta \mathrm{V}_{\mathrm{t}}\right)$, which appears around $2 \mathrm{~ms}$ (Fig. $\left.2 D\right)$, is strongly 

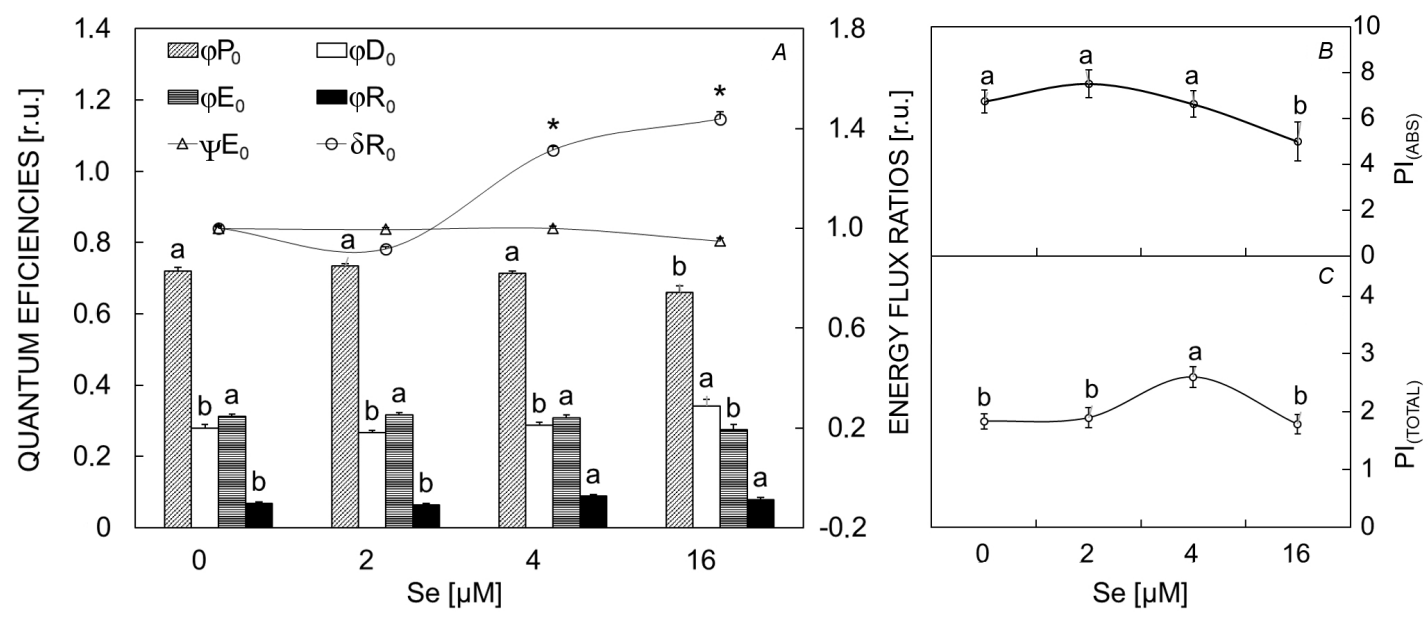

Fig. 6. Photochemical parameters derived from the analysis of the JIP test ( $\psi \mathrm{E}_{0}$ - probability that a trapped exciton moves an electron into the electron transport chain beyond $\mathrm{Q}_{\mathrm{A}}^{-} ; \varphi \mathrm{D}_{0}$ - quantum yield of energy dissipation; $\varphi \mathrm{E}_{0}$ - quantum yield of electron transport; $\varphi \mathrm{P}_{0}-$ maximum quantum yield of primary photochemistry; $\varphi \mathrm{R}_{0}$ - quantum yield of reduction of end electron acceptors at the PSI acceptor side; $\delta \mathrm{R}_{0}$ - efficiency/probability with which an electron from the intersystem electron carriers moves to reduce end electron acceptors at the PSI acceptor side) of in vitro grown Billbergia zebrina plants as a function of Se concentration $(0,2,4$, and $16 \mu \mathrm{M})(A)$. The lines (secondary ordinate scale on the right) represent the normalized values according to the control $(0 \mu \mathrm{M})$. The asterisk $(*)$ represents a difference between the treatments with selenium in relation to the control according to the Scott-Knott's test $(p<0.05)$. Performance index based on absorption $\left(\mathrm{PI}_{(\mathrm{ABS})}\right)(B)$ and overall performance index, which measures the performance up until the final electron acceptors of PSI $\left(\mathrm{PI}_{(\text {Total })}\right)(C)$ of Billbergia zebrina plants under Se treatments. In all graphs, means $\pm \mathrm{SD}(n=15)$ followed by the same letter are not significantly different according to the Scott-Knott's test $(p<0.05)$.

influenced by the redox reactions of the initial acceptors, especially $\mathrm{Q}_{\mathrm{A}}$ (Strasser et al. 2010, Krüger et al. 2014). Hence, a positive band, such as that observed in the samples cultivated in the presence of $16 \mu \mathrm{M}$ Se, suggests that high concentrations of Se reduce the probability of electrons moving from the intersystem to the PSI from the $\mathrm{Q}_{\mathrm{A}}^{-}$(Strasser et al. 2000). On the other hand, for the $B$. zebrina plants cultivated in all other Se treatments, there was no difference in relation to the control (Fig. 2D). This result likely indicates stability in the water electron donation in relation to an increase or maintenance of the PSI activity, as observed by Krüger et al. (2014) in studies with different temperatures. Or, as suggested by Christen et al. (2007) in studies with grapevines under biotic and abiotic stress, a negative J-band may suggest an increase in the capacity to reoxidize the pool of quinones.

According to Oukarroum et al. (2009), analyses of both L- and K-bands are good references to characterize physiological disturbances in plants. The L-band, which appears at approximately $0.15 \mathrm{~ms}$, indicates energetic connectivity (grouping) of the PSII units (Strasser et al. 2004). Therefore, a positive L-band, such as that observed in plants cultivated with $16 \mu \mathrm{M} \mathrm{Se}$ (Fig. $3 A$ ), suggests that high concentrations of Se make the energetic cooperation among the PSII units less stable (Pollastrini et al. 2017). Such phenomenon is likely associated with disorganization in the thylakoid membranes (Oukarroum et al. 2007). However, the negative differences observed in the plants submitted to 2 and $4 \mu \mathrm{M}$ Se indicate stronger connectivity (Fig. 3A), which results in better use of the excitement energy and higher stability of the system (Strasser et al. 2004).

The K-band appears at approximately $0.3 \mathrm{~ms}$ (Fig. 3B) and expresses the electron donation activity from the oxygen-evolving complex (OEC) to the PSII, which accordingly competes with electron donations not coming from water (Pollastrini et al. 2017). A positive K-band, such as the one observed in plants grown with $16 \mu \mathrm{M} \mathrm{Se}$ (Fig. 3B), indicates loss of OEC integrity, weakening the stability of oxygen evolution by the $\mathrm{Mn}_{4} \mathrm{CaO}_{5}$ complex as an electron donor to the PSII (Gururani et al. 2012).

Strasser et al. (2000) reported alteration in the OEC, enabling alternative electron donors to transfer electrons to the PSII, leading to an increase in the $\mathrm{Pheo}^{-}$and $\mathrm{Q}_{\mathrm{A}}^{-}$, and therefore generating a positive K-band. Since the OEC gives access to electron donors not coming from water, such as ascorbate (Tóth et al. 2011), proline (De Ronde et al. 2004) or any other internal donor with an electropotential more negative than the $\mathrm{H}_{2} \mathrm{O} / \mathrm{O}_{2}$ reaction, its malfunctioning can be compensated by these donors for a short period of time (Gururani et al. 2012). Positive values for the K-band may also indicate an increase in the functional antenna size associated with the PSII (Yusuf et al. 2010), as well as damages between the donor and acceptor sides of the PSII, resulting from an imbalance between the OEC electron flow to the reaction center and the acceptor side of the PSII towards the PSI (Strasser 1997, Chen and Cheng 2010). A negative K-band, such as those observed in plants grown with 2 and $4 \mu \mathrm{M}$ Se in relation to the control (Fig. 3B), indicates an increase in the OEC functioning and integrity of the $\mathrm{Mn}_{4} \mathrm{CaO}_{5}$ complex. This condition could restrict the entrance of electrons not coming from water, thus causing higher efficiency of the OEC in the donation of electrons to the PSII (De Ronde et al. 2004). The I-P phase refers to the events of electron transfer associated with the PSI (Schansker et al. 2003, Redillas et al. 2011), and it was 
the stage of highest influence of Se on photosynthetic apparatus in the analyzed samples. The curves $\mathrm{V}_{\mathrm{OI}} \geq 1.0$ of higher amplitude observed in the treatments with 4 and $16 \mu \mathrm{M} \mathrm{Se}$ (Fig. $4 A$ ) are also an indication of the dynamic modulations of the electron transport from the intersystem to the PSI (Yusuf et al. 2010). In addition, it also suggests an increase in the pool size of the final electron acceptors from the acceptor side of the PSI. The largest values of $\Delta V_{I P}$ were also observed in these treatments (Fig. 4B), indicating a higher contribution relative to the I-P phase to the curve of emission of the Chl $a$ fluorescence and the abundance of units of the PSI (Ceppi et al. 2012). Schansker et al. (2005) demonstrated that the increase in the relative contribution of the I-P phase to the fluorescence curve depends both on the electron flow through the PSI and blockage of the electron flow in the acceptor side of the PSI.

The normalization $\mathrm{V}_{\text {IP }}$ allows a deduction in the electron flow behavior coming from the intersystem to the final acceptors of the PSI (Martins et al. 2017), thus enabling an estimation of the global rate of reduction of the final acceptors of the PSI (Fig. 4B). Plants cultivated with 4 and $16 \mu \mathrm{M}$ Se presented a decrease in $\mathrm{V}_{\text {IP }}$ (Fig. $4 B$ ), as described by the Michaelis-Menten equation, where the inverse of the time to reach $\mathrm{V}_{\text {IP }}=0.5$ is the determinant of the decrease in the reducing capacity of the PSI (Yusuf et al. 2010). The data from the plants cultivated with 4 and $16 \mu \mathrm{M}$ Se suggest that addition of Se to the growth medium does not imply proportionality between the global rate of reduction of the final receptors of the PSI and the amount of time and light necessary to reach $50 \%$ of the emission of the I-P phase (determined by the relative variable fluorescence between points I-P or $\Delta \mathrm{V}_{\mathrm{IP}}$ ) (Yusuf et al. 2010, Martins et al. 2017) (Fig. 4B,C). However, this demand for time and light encountered by the analysis of $\Delta V_{I P}$ seems proportional to an increase in PSI units and relative contribution of the I-P phase to the Chl $a$ fluorescence emission curve, as observed in the samples cultivated with 4 and $16 \mu \mathrm{M}$ Se (Fig. 4B,C). Accordingly, Se can induce an increase in the PSI activity. The importance of these mechanisms is in the photooxidative reduction, directing electrons to alternative routes to the electron cyclic flow involving the PSI, thus decreasing the formation of ROS (Oukarroum et al. 2015) and increasing the ferredoxin-Fd reductase, other intermediates, and $\mathrm{NADP}^{+}$(Yusuf et al. 2010, Redillas et al. 2011).

The parameters of the JIP test derived from the OJIP transients can be used to characterize the behavior/activity of the PSII, intersystem, and PSI (Strasser et al. 2004, Strauss et al. 2006, Tsimilli-Michael and Strasser 2013). These parameters are considered efficient in targeting different sites of action and the heterogeneity of the PSII (Appenroth et al. 2001, Kalaji et al. 2014). For example, the increase in $\mathrm{ABS} / \mathrm{RC}$ with $16 \mu \mathrm{M}$ Se can be attributed to two factors. The first is the increase in the functional antenna size associated with the PSII, which provides the reaction centers with excitement energy (Yusuf et al. $2010)$. Since the $\mathrm{TR}_{0} / \mathrm{RC}$ increased proportionally to $\mathrm{ABS} / \mathrm{RC}$ in plants cultivated with $16 \mu \mathrm{M}$ Se, it is possible to suggest a weakening in the dynamics of electron transport from OEC to the PSII (Chen et al. 2014, Kalaji et al. 2014), as well as the transfer of excitement energy from the inactive to the active reaction centers (Lavergne and Leci 1993) (Fig. 5). In plants cultivated with $16 \mu \mathrm{M} \mathrm{Se}$, there was also a decrease in RC/ABS (Fig. 5), a parameter that indicates the stability of the reaction centers and their connection to other light-harvesting antenna complexes (Chen et al. 2014). This condition implies the second factor for the increase in $\mathrm{ABS} / \mathrm{RC}$, i.e., the inactivation of a fraction of the active reaction centers, transforming them into nonreducers of $\mathrm{Q}_{\mathrm{A}}$ (Yusuf et al. 2010, Redillas et al. 2011).

Decreases in RC/ABS can be an indication of susceptibility to photoinhibition and formation of silent reaction centers (Chen et al. 2014). Accordingly, it can be inferred that the size of the $\mathrm{ABS} / \mathrm{RC}$ and $\mathrm{TR}_{0} / \mathrm{RC}$ associated with the increase in $\mathrm{DI}_{0} / \mathrm{RC}$ observed after the growth of plants with $16 \mu \mathrm{M}$ Se characterizes a structural transformation in the reaction centers into units that dissipate excitement energy in the form of heat (Strasser et al. 2004) (Fig. 5). This condition could avoid the overproduction of $\mathrm{Q}_{\mathrm{A}}^{-}$(Redillas et al. 2011) and reduce the formation of ROS, thus protecting the excitement system and excessive reduction (Chen et al. 2014). The sequence of parameters that characterize the transduction of energy from the reaction centers or the PSII is the absorption $(\mathrm{ABS} / \mathrm{RC})$, capture $\left(\mathrm{TR}_{0} / \mathrm{RC}\right)$, and transport of electrons $\left(\mathrm{ET}_{0} / \mathrm{RC}\right)$. In the present study, no alterations were observed to the JIP test parameters in treatments with low Se concentrations ( 2 and $4 \mu \mathrm{M}$ ) (Fig. 5). Finally, the analysis of $\mathrm{RE}_{0} / \mathrm{RC}$ values, related to the reduction of the final acceptors of the PSI, allowed verifying the significant increases obtained with 4 and $16 \mu \mathrm{M}$ Se (Fig. 5). These results indicate an increase in the contribution in the I-P phase to the OJIP transient, corroborating the observations of Oukarroum et al. (2009) and Paillotin (1976). Within these Se concentrations, the electron transport capacity between $\mathrm{Q}_{\mathrm{A}}^{-}$and the PSI acceptors was increased.

In this study, decreases in the photochemical quantum yield of the PSII were obtained from the plants cultivated with $16 \mu \mathrm{M} \mathrm{Se}$, which according to Hermans et al. (2003) can be related to the conversion of the $\mathrm{Q}_{\mathrm{A}}$ reducing center into nonreducing or dissipating centers (Fig. 6A), as described previously when analyzing the results obtained for $\mathrm{ABS} / \mathrm{RC}, \mathrm{RC} / \mathrm{ABS}$, and $\mathrm{DI}_{0} / \mathrm{RC}$ (Fig. 5). Decreases in $\varphi \mathrm{P}_{0}$ can be considered indicative of photoinhibitory damages to the PSII complex (Baker and Rosenqvist 2004). This condition can alter the shape of the OJIP curves, either by decreasing $\mathrm{F}_{\mathrm{m}}$ or by increasing $\mathrm{F}_{0}$ (Lin et al. 2009), as observed in plants grown with $16 \mu \mathrm{M}$ Se (Fig. 6A). According to Oukarroum et al. (2009), these alterations reduce the efficiency by which an absorbed photon can be captured by the reaction center of the PSII. All these structural parameters of the JIP test characterize the events related to the PSII structure and intersystem $\left(\varphi \mathrm{P}_{0}, \varphi \mathrm{D}_{0}\right.$, and $\left.\varphi \mathrm{E}_{0}\right)$ or $\mathrm{O}-\mathrm{J}$ and $\mathrm{J}-\mathrm{I}$ phases, respectively (Strasser et al. 2004, Tsimilli-Michael and Strasser 2008), which did not differ between the Se concentrations of 0,2 , and $4 \mu \mathrm{M}$ (Fig. $6 A$ ). Hence, this result suggests that at these concentrations of Se, the stability of the PSII and intersystem is maintained without any signs of increase or 
decrease. On the contrary, the lower values observed for $\varphi \mathrm{P}_{0}$ and $\varphi \mathrm{E}_{0}$ followed by an increase in $\varphi \mathrm{D}_{0}$ in the plants cultivated with $16 \mu \mathrm{M}$ Se reinforces the occurrence of photoinhibition (Fig. 6A), indicating a reduction in the dynamics of transport and use of excitement energy (Zhuo et al. 2017), and therefore limiting the growth of B. zebrina at higher Se concentrations. Increases in the electron transfer across the intersystem to the reduction of the final acceptors of PSI occurred in the B. zebrina plants grown with 4 and $16 \mu \mathrm{M}$ Se in relation to all other treatments (Fig. 6A). The intersystem and PSI can be potential sites of action for Se. This inference is based on the increase in the efficiency in the electron transfer from the reduced plastoquinone to the PSI acceptor side, evaluated by means of the $\delta \mathrm{R}_{0}$ parameter analysis (Oukarroum et al. 2009), observed in the plants grown with 4 and $16 \mu \mathrm{M} \mathrm{Se}$ (Fig. $6 A$ ). Also, increases in these treatments were also observed when the quantum yield was evaluated regarding reduction of the final acceptors of the PSI (Tsimilli-Michael and Strasser 2008) (Fig. 6A). This increase in stability with reduction of PSI final acceptors attributed to Se most likely indicates an increase in the number of reaction centers associated with the PSI (Oukarroum et al. 2009).

Finally, the indexes of vitality $\left(\mathrm{PI}_{(\mathrm{ABS})}\right.$ and $\left.\mathrm{PI}_{(\text {Total })}\right)$ represent a product of some independent functional and structural parameters (Strasser et al. 2004, Kalaji et al. 2016). Higher values of PI indicate an increase in the potential energy conservation ability of the photosynthetic apparatus (Yusuf et al. 2010). Similarity of the $\mathrm{PI}_{(\mathrm{ABS})}$ values of plants cultivated with 0,2 , and $4 \mu \mathrm{M}$ Se indicate that selenium maintains the potential capacity of energy conservation for the reduction of the electron acceptors to the intersystem (Yusuf et al. 2010, Redillas et al. 2011, Krüger et al. 2014, Chen et al. 2015) (Fig. 6B). With respect to the $\mathrm{PI}_{(\text {Total) }}$, only the plants grown with $4 \mu \mathrm{M} \mathrm{Se}$ had increases in the energy conservation capacity of the photosynthetic apparatus (Fig. $6 \mathrm{C}$ ). $\mathrm{PI}_{\text {(Total) }}$ encompasses, in addition to $\mathrm{PI}_{(\mathrm{ABS})}$, the likelihood that an electron from the intersystem moves to reduce the final acceptors on the acceptor side of the PSI $\left(\delta \mathrm{R}_{0}\right)$ (Tsimilli-Michael and Strasser 2008), in which increases were observed (approximately $30 \%$ ) of plants cultivated with $4 \mu \mathrm{M}$ Se. This increase in $\delta \mathrm{R}_{0}$ made the $\mathrm{PI}_{\text {(Total) }}$ values of plants grown with $4 \mu \mathrm{M}$ Se more pronounced and suggests, again, that the site of action of selenium may be between the intersystem and the PSI (Fig. 6C). Since $\mathrm{PI}_{\text {(Total) }}$ incorporated parameters that characterize all the phases of the OJIP, it is considered by several authors to be the most sensitive JIP test parameter to characterize the physiological state of plants under different abiotic conditions (Strasser et al. 2004, Oukarroum et al. 2007, Yusuf et al. 2010, Brestič and Živčák 2013, Kalaji et al. 2014).

Conclusion: This study demonstrated that at 2 and $4 \mu \mathrm{M}$ Se, the stability of the energy transport reaction in the PSII in $B$. zebrina were maintained. Furthermore, the potential capacity of energy conservation in the photosynthetic apparatus $\left(\mathrm{PI}_{(\mathrm{Total})}\right)$ was improved at $4 \mu \mathrm{M}$ Se. The enhancement of the electron transport dynamics from the intersystem to the PSI (evaluating $\delta \mathrm{R}_{0}$ and $\varphi \mathrm{R}_{0}$ ) reported to the higher Se concentrations suggests the PSI the mainly site of action of Se within the photosynthetic apparatus. Accordingly, using B. zebrina as a model, we can infer that at 2 and $4 \mu \mathrm{M}$ Se can cause increases in the structure and functionality of the photosynthetic apparatus. In addition, we observed that $B$. zebrina showed physiological disturbances at $16 \mu \mathrm{M} \mathrm{Se}$, displaying impaired growth and photosynthetic pigments content, and instability in the structure and functionality of the photosynthetic apparatus, especially in the PSII. Hence, from the ecotoxicological standpoint, the excess of Se was toxic to the studied species.

\section{References}

Appenroth K.J., Stöckel J., Srivastava A., Strasser R.J.: Multiple effects of chromate on the photosynthetic apparatus of Spirodela polyrhiza as probed by OJIP chlorophyll $a$ fluorescence measurements. - Environ. Pollut. 115: 49-64, 2001.

Arnon D.I.: Copper enzymes in isolated chloroplasts. Polyphenoloxidase in Beta vulgaris. - Plant Physiol. 24: 1-15, 1949.

Bachiega P., Salgado J.M., de Carvalho J.E. et al.: Antioxidant and antiproliferative activities in different maturation stages of broccoli (Brassica oleracea Italica) biofortified with selenium. - Food Chem. 190: 771-776, 2016.

Baker N.R., Rosenqvist E.: Applications of chlorophyll fluorescence can improve crop production strategies: an examination of future possibilities. - J. Exp. Bot. 55: 1607-1621, 2004.

Blackburn G.A.: Hyperspectral remote sensing of plant pigments.J. Exp. Bot. 58: 855-867, 2007.

Brestič M., Živčák M.: PSII fluorescence techniques for measurement of drought and high temperature stress signal in crop plants: protocols and applications. - In: Das A.B., Rout G.R. (ed.): Molecular Stress Physiology of Plants. Pp. 87-131. Springer, New Delhi 2013.

Broyer T.C., Lee D.C., Asher C.J.: Selenium nutrition of green plants. Effect of selenite supply on growth and selenium content of alfalfa and subterranean clover. - Plant Physiol. 41: 1425-1428, 1966.

Ceppi M.G., Oukarroum A., Çiçek N. et al.: The IP amplitude of the fluorescence rise OJIP is sensitive to changes in the photosystem I content of leaves: a study on plants exposed to magnesium and sulfate deficiencies, drought stress and salt stress. - Physiol. Plantarum 144: 277-288, 2012.

Chen L.S., Cheng L.: The acceptor side of photosystem II is damaged more severely than the donor side of photosystem II in 'Honeycrisp' apple leaves with zonal cholorosis. - Acta Physiol. Plant. 32: 253-261, 2010.

Chen Q., Guan T., Yun L. et al.: Online forecasting chlorophyll $a$ concentrations by an auto-regressive integrated moving average model: Feasibilities and potentials. - Harmful Algae 43: 58-65, 2015.

Chen S.G., Strasser R.J., Qiang S.: In vivo assessment of effect of phytotoxin tenuazonic acid on PSII reaction centers. - Plant Physiol. Bioch. 84: 10-21, 2014.

Christen D., Schönmann S., Jermini M. et al.: Characterization and early detection of grapevine (Vitis vinifera) stress responses to esca disease by in situ chlorophyll fluorescence and comparison with drought stress. - Environ. Exp. Bot. 60: 504-514, 2007.

De Ronde J.A., Cress W.A., Krüger G.H.J. et al.: Photosynthetic response of transgenic soybean plants, containing an Arabidopsis P5CR gene, during heat and drought stress. J. Plant Physiol. 161: 1211-1224, 2004.

Diao M., Ma L., Wang J. et al.: Selenium promotes the growth 
and photosynthesis of tomato seedlings under salt stress by enhancing chloroplast antioxidant defense system. - J. Plant Growth Regul. 33: 671-682, 2014.

Djanaguiraman M., Durga Devi D., Shanker A.K. et al.: Selenium: an antioxidative protectant in soybean during senescence. - Plant Soil 272: 77-86, 2005

Djanaguiraman M., Prasad P.V.V., Seppänen M.: Selenium protects sorghum leaves from oxidative damage under high temperature stress by enhancing antioxidant defense system. Plant Physiol. Bioch. 48: 999-1007, 2010.

Feng R.W., Liao G.J., Guo J.K. et al.: Responses of root growth and antioxidative systems of paddy rice exposed to antimony and selenium. - Environ. Exp. Bot. 122: 29-38, 2016.

Feng R.W., Wei C.Y.: Antioxidative mechanisms on selenium accumulation in Pteris vittata L., a potential selenium phytoremediation plant. - Plant Soil Environ. 58: 105-110, 2012.

Feng R.W., Wei C.Y., Tu S.X.: The roles of selenium in protecting plants against abiotic stresses. - Environ. Exp. Bot. 87: 58-68, 2013.

Feng T., Chen S.S., Gao D.Q. et al.: Selenium improves photosynthesis and protects photosystem II in pear (Pyrus bretschneideri), grape (Vitis vinifera), and peach (Prunus persica). - Photosynthetica 53: 609-612, 2015.

Gururani M.A., Upadhyaya C.P., Strasser R.J. et al.: Physiological and biochemical responses of transgenic potato plants with altered expression of PSII manganese stabilizing protein. Plant Physiol. Bioch. 58: 182-194, 2012.

Han D., Xiong S.L., Tu S.X. et al.: Interactive effects of selenium and arsenic on growth, antioxidant system, arsenic and selenium species of Nicotiana tabacum L. - Environ. Exp. Bot. 117: 12-19, 2015.

Hanson B., Garifullina G.F., Lindblom S.D. et al.: Selenium accumulation protects Brassica juncea from invertebrate herbivory and fungal infection. - New Phytol. 159: 461-469, 2003.

Hartikainen H., Ekholm P., Piironen V. et al.: Quality of the ryegrass and lettuce yields as affected by selenium fertilization. - Agr. Food Sci. Finland 6: 381-387, 1997.

Hartikainen H., Xue T.L., Piironen V.: Selenium as Na antioxidant and pro-oxidant in ryegrass. - Plant Soil 225: 193200, 2000.

Hasanuzzaman M., Fujita M.: Selenium pretreatment upregulates the antioxidant defense and methylglyoxal detoxification system and confers enhanced tolerance to drought stress in rapeseed seedlings. - Biol. Trace Elem. Res. 143: 1758-1776, 2011.

Hermans C., Smeyers M., Rodriguez R.M. et al:: Quality assessment of urban trees: A comparative study of physiological characterisation, airborne imaging and on site fluorescence monitoring by the OJIP-test. - J. Plant Physiol. 160: 81-90, 2003.

Jiang H.X., Yang L.T., Qi Y.P. et al.: Root iTRAQ protein profile analysis of two citrus species differing in aluminumtolerance in response to long-term aluminum-toxicity. - BMC Genomics 16: 949-966, 2015.

Kalaji H.M., Jajoo A., Oukarroum A. et al:: Chlorophyll a fluorescence as a tool to monitor physiological status of plants under abiotic stress conditions. - Acta Physiol. Plant. 38: 102, 2016.

Kalaji H.M., Oukarroum A., Alexandrov V. et al.: Identification of nutrient deficiency in maize and tomato plants by in vivo chlorophyll $a$ fluorescence measurements. - Plant Physiol. Bioch. 81: 16-25, 2014

Krüger G.H.J., De Villiers M.F., Strauss A.J. et al.: Inhibition of photosystem II activities in soybean (Glycine max) genotypes differing in chilling sensitivity. - S. Afr. J. Bot. 95: 85-96,
2014.

Kryukov G.V., Castellano S., Novoselov S.V. et al.: Characterization of mammalian selenoproteomes. - Science 300: 14391443, 2003.

Łabanowska M., Filek M., Kościelniak J. et al.: The effects of short-term selenium stress on Polish and Finnish wheat seedlings - EPR, enzymatic and fluorescence studies. J. Plant Physiol. 169: 275-284, 2012.

Lambers H. Chapin III F.S., Pons T.L.: Plant Physiological Ecology. $2^{\text {nd }}$ Edition. Pp. 604. Springer-Verlag, New York 2008.

Lavergne J., Leci E.: Properties of inactive photosystem II centers. - Photosynth. Res. 35: 323-343, 1993.

Lichtenthaler H.K.: Chlorophylls and carotenoids: Pigments of photosynthetic biomembranes. - Method. Enzymol. 148: 350-382, 1987.

Lin Z.H., Chen L.S., Chen R.B. et al.: $\mathrm{CO}_{2}$ assimilation, ribulose1,5-biphosphate carboxylase/oxygenase, carbohydrates and photosynthetic electron transport probed by the JIP-test, of tea leaves in response to phosphorus supply. - BMC Plant Biol. 9: 43, 2009.

Lindblom S.D., Valdez-Barillas J.R., Fakra S.C. et al.: Influence of microbial associations on selenium localization and speciation in roots of Astragalus and Stanleya hyperaccumulators. Environ. Exp. Bot. 88: 33-42, 2013.

Martins J.P.R., Martins A.D., Ferreira Pires M.F. et al.: Anatomical and physiological responses of Billbergia zebrina (Bromeliaceae) to copper excess in a controlled microenvironment. - Plant Cell Tiss. Org. 126: 43-57, 2016.

Martins R.F.A., Souza A.F.C., Pitol C., Falqueto A.R.: Physiological responses to intense water deficit in two genotypes of crambe (Crambe abyssinica Hochst.). - Aust. J. Crop Sci. 11: 821-827, 2017.

Mehta P., Jajoo A., Mathur S., Bharti S.: Chlorophyll a fluorescence study revealing effects of high salt stress on Photosystem II in wheat leaves. - Plant Physiol. Bioch. 48: 16-20, 2010.

Murashige T., Skoog F.: A revised medium for rapid growth and bio-assays with tobacco tissue cultures. - Physiol. Plantarum 15: 473-497, 1962.

Ning N., Yuan X.Y., Dong S.Q. et al.: Increasing selenium and yellow pigment concentrations in foxtail millet (Setaria italica L.) grain with foliar application of selenite. - Biol. Trace Elem. Res. 170: 245-252, 2016.

Oukarroum A., Bussotti F., Goltsev V. et al.: Correlation between reactive oxygen species production and photochemistry of photosystems I and II in Lemna gibba L. plants under salt stress. - Environ. Exp. Bot. 109: 80-88, 2015.

Oukarroum A., Madidi S.E.L., Schansker G., Strasser R.J.: Probing the responses of barley cultivars (Hordeum vulgare L.) by chlorophyll $a$ fluorescence OLKJIP under drought stress and re-watering. - Environ. Exp. Bot. 60: 438-446, 2007.

Oukarroum A., Schansker G., Strasser R.J.: Drought stress effects on photosystem I content and photosystem II thermotolerance analyzed using $\mathrm{Chl} a$ fluorescence kinetics in barley varieties differing in their drought tolerance. - Physiol. Plantarum 137: 188-199, 2009.

Owusu-Sekyere A., Kontturi J., Hajiboland R. et al.: Influence of selenium ( $\mathrm{Se}$ ) on carbohydrate metabolism, nodulation and growth in alfalfa (Medicago sativa L.). - Plant Soil 373: 541552, 2013.

Paillotin G.: Movement of excitations in the photosynthetic domains of photosystem I. - J. Theor. Biol. 58: 337-352, 1976.

Pilon-Smith E.A.H., Quin C., Tapken W. et al.: Physiological functions of beneficial elements. - Curr. Opin. Plant Biol. 12: 267-274, 2009. 
Pilon-Smits E.A.H., LeDuc D.L.: Phytoremediation of selenium using transgenic plants. - Curr. Opin. Biotech. 20: 207-212, 2009.

Pollastrini M., Nogales A.G., Benavides R. et al.: Tree diversity affects chlorophyll $a$ fluorescence and other leaf traits of tree species in a boreal forest. - Tree Physiol. 37: 199-208, 2017.

Qing X., Zhao X., Hu C. et al.: Selenium alleviates chromium toxicity by preventing oxidative stress in cabbage (Brassica campestris L. ssp. Pekinensis) leaves. - Ecotox. Environ. Safe. 114: 179-189, 2015.

Redillas M.C.F.R., Strasser R.J., Jeong J.S. et al.: The use of JIP test to evaluate drought-tolerance of transgenic rice overexpressing OsNAC10. - Plant Biotechnol. Rep. 5: 169175, 2011.

Schansker G., Srivastava A., Govindjee, Strasser R.J.: Characterization of the 820 -nm transmission signal paralleling the chlorophyll $a$ fluorescence rise (OJIP) in pea leaves. Funct. Plant Biol. 30: 785-796, 2003.

Schansker G., Tóth S.Z., Strasser R.J.: Methylviologen and dibromothymoquinone treatments of pea leaves reveal the role of photosystem I in the $\mathrm{Chl} a$ fluorescence rise OJIP. BBA-Bioenergetics 1706: 250-261, 2005.

Seppänen M., Turakainen M., Hartikainen H.: Selenium effects on oxidative stress in potato. - Plant Sci. 165: 311-319, 2003.

Stadtman T.C.: Selenocysteine. - Annu. Rev. Biochem. 65: 83$100,1996$.

Strasser B.J., Strasser R.J.: Measuring fast fluorescence transient to address environmental questions: The JIP-test. - In: Mathis P. (ed.): Photosynthesis: From Light to Biosphere. Pp. 977980. Kluwer Academic Publishers, Dordrecht 1995.

Strasser B.J.: Donor side capacity of Photosystem II probed by chlorophyll $a$ fluorescence transients. - Photosynth. Res. 52: $147-155,1997$.

Strasser R.J., Srivastava A., Tsimilli-Michael M.: The fluorescence transient as a tool to characterize and screen photosynthetic samples. - In: Yunus M., Pathre U., Mohanty P. (ed.): Probing Photosynthesis: Mechanisms, Regulation and Adaptation. Pp. 445-483. Taylor and Francis, London 2000.

Strasser R.J., Tsimilli-Michael M., Qiang S., Goltsev V.: Simultaneous in vivo recording of prompt and delayed fluorescence and 820-nm reflection changes during drying and after rehydration of the resurrection plant Haberlea rhodopensis. - BBA-Bioenergetics 1797: 1313-1326, 2010.

Strasser R.J., Tsimilli-Michael M., Srivastava A.: Analysis of the chlorophyll $a$ fluorescence transient. - In: Papageorgiou G.C., Govindjee (ed.): Chlorophyll $a$ Fluorescence: A Signature of Photosynthesis. Advances in Photosynthesis and Respiration. Pp. 321-362. Springer, Dordrecht 2004.

Strauss A.J., Krüger G.H.J., Strasser R.J., Heerden P.D.R.V.: Ranking of dark chilling tolerance in soybean genotypes probed by the chlorophyll $a$ fluorescence transient O-J-I-P. Environ. Exp. Bot. 56: 147-157, 2006.

Tang H., Liu Y., Gong X. et al.: Effects of selenium and silicon on enhancing antioxidative capacity in ramie (Boehmeria nivea L. Gaud.) under cadmium stress. - Environ. Sci. Pollut. R. 22: 9999-10008, 2015.

Tausz M., Hietz P., Briones O.: The significance of carotenoids and tocopherols in photoprotection of seven epiphytic fern species of a Mexican cloud forest. - Aust. J. Plant Physiol. 28: 775-783, 2001.
Terry N., Zayed A.M., De Souza M.P., Tarun A.S.: Selenium in higher plants. - Annu. Rev. Plant Phys. 51: 401-432, 2000.

Tian M., Xu X., Liu Y. et al.: Effect of Se treatment on glucosinolate metabolism and health-promoting compounds in the broccoli sprouts of three cultivars. - Food Chem. 190: 374-380, 2016.

Tóth S.Z., Nagy V., Puthur J.T. et al.: The physiological role of ascorbate as photosystem II electron donor: Protection against photoinactivation in heat-stressed leaves. - Plant Physiol. 156: 382-392, 2011.

Tsimilli-Michael M., Strasser R.J.: In vivo assessment of stress impact on plants' vitality: applications in detecting and evaluating the beneficial role of mycorrhization on host plants. - In: Varma A. (ed.): Mycorrhiza. State of the Art, Genetics and Molecular Biology, Eco-Function, Biotechnology, Eco-Physiology, Structure and Systematics. $3^{\text {rd }}$ edition. Pp. 679-703. Springer, Berlin-Heidelberg 2008.

Tsimilli-Michael M., Strasser R.J.: The energy flux theory 35 years later: formulations and applications. - Photosynth. Res. 117: 289-320, 2013.

Turakainen M., Hartikainen H., Ekholm P., Seppänen M.M.: Distribution of selenium in different biochemical fractions and raw darkening degree of potato (Solanum tuberosum) tubers supplemented with selenate. - J. Agr. Food Chem. 54: 8617-8622, 2006.

Vítová M., Bišová K., Hlavová M. et al:: Glutathione peroxidase activity in the selenium-treated alga Scenedesmus quadricauda. - Aquat. Toxicol. 102: 87-94, 2011.

Wang Y.D., Wang X., Wong Y.S.: Proteomics analysis reveals multiple regulatory mechanisms in response to selenium in rice. - J. Proteomics 75: 1849-1866, 2012.

Xue T., Hartikainen H., Piironen V.: Antioxidative and growth promoting effect of selenium in senescing lettuce. - Plant Soil 237: 55-61, 2001.

Yao X.Q., Chu J.Z., Ba C.J.: Responses of wheat roots to exogenous selenium supply under enhanced ultraviolet-B. Biol. Trace Elem. Res. 137: 244-252, 2010.

Yusuf M.A., Kumar D., Rajwanshi R. et al.: Overexpression of $\gamma$-tocopherol methyl transferase gene in transgenic Brassica juncea plants alleviates abiotic stress: Physiological and chlorophyll a fluorescence measurements. - BBABioenergetics 1797: 1428-1438, 2010.

Zhang L., Ackley A.R., Pilon-Smits E.A.H.: Variation in selenium tolerance and accumulation among Arabidopsis thaliana accessions. - Plant Physiol. 164: 327-336, 2007.

Zhong N., Zhong L., Hao L. et al.: Speciation of selenium in enriched garlic sprouts by high-performance liquid chromatography coupled with inductively coupled plasmamass spectrometry. - Anal. Lett. 48: 180-187, 2015.

Zhu Y.G., Pilon-Smits E.A.H., Zhao F.J. et al.: Selenium in higher plants: understanding mechanisms for biofortification and phytoremediation. - Trends Plant Sci. 14: 436-442, 2009.

Zhuo Y., Qiu S., Amombo E. et al.: Nitric oxide alleviates cadmium toxicity in tall fescue photosystem II on the electron donor side. - Environ. Exp. Bot. 137: 110-118, 2017.

Zushi K., Matsuzoe N.: Using of chlorophyll $a$ fluorescence OJIP transients for sensing salt stress in the leaves and fruits of tomato. - Sci. Hortic.-Amsterdam 219: 216-221, 2017. 
Appendix. Abbreviations of the parameters, formulas and description of the data derived from the transient fluorescence of chlorophyll $a$. For review see Strasser et al. (2004) and Yusuf et al. (2010).

\begin{tabular}{|c|c|}
\hline Fluorescence parameters & Description \\
\hline \multicolumn{2}{|l|}{ Extracted fluorescence parameters } \\
\hline $\mathrm{F}_{20 \mu \mathrm{s}}$ & Fluorescence intensity at $20 \mu \mathrm{s}$ \\
\hline $\mathrm{F}_{\mathrm{K}}=\mathrm{F}_{0.3 \mathrm{~ms}}$ & Fluorescence intensity at $0.3 \mathrm{~ms}$ \\
\hline $\mathrm{F}_{\mathrm{J}}=\mathrm{F}_{2 \mathrm{~ms}}$ & Fluorescence intensity at $2 \mathrm{~ms}$ \\
\hline $\mathrm{F}_{\mathrm{I}}=\mathrm{F}_{30 \mathrm{~ms}}$ & Fluorescence intensity at $30 \mathrm{~ms}$ \\
\hline $\mathrm{F}_{\mathrm{P}}=\mathrm{F}_{300 \mathrm{~ms}}$ & Fluorescence intensity at $300 \mathrm{~ms}$ \\
\hline \multicolumn{2}{|l|}{ Technical parameters } \\
\hline $\mathrm{F}_{0}=\mathrm{F}_{0.02 \mathrm{~ms}}$ & Initial fluorescence \\
\hline $\mathrm{F}_{\mathrm{m}}=\mathrm{F}_{300 \mathrm{~ms}}$ & Maximum fluorescence \\
\hline $\mathrm{F}_{\mathrm{v}}=\mathrm{F}_{\mathrm{m}}-\mathrm{F}_{0}$ & Variable fluorescence \\
\hline $\mathrm{M}_{0}=\mathrm{d}_{\mathrm{V}} / \mathrm{dt}_{0}=4 \times\left(\mathrm{F}_{300 \mu \mathrm{s}}-\mathrm{F}_{0}\right) /\left(\mathrm{F}_{\mathrm{m}}-\mathrm{F}_{0}\right)$ & Net rate of photosystem II closure \\
\hline $\mathrm{V}_{\mathrm{J}}=\left(\mathrm{F}_{2 \mathrm{~ms}}-\mathrm{F}_{0}\right) /\left(\mathrm{F}_{\mathrm{m}}-\mathrm{F}_{0}\right)$ & Relative variable fluorescence at $2 \mathrm{~ms}$ (point $\mathrm{J}$ ) \\
\hline $\mathrm{V}_{\mathrm{I}}=\left(\mathrm{F}_{30 \mathrm{~ms}}-\mathrm{F}_{0}\right) /\left(\mathrm{F}_{\mathrm{m}}-\mathrm{F}_{0}\right)$ & Relative variable fluorescence at $30 \mathrm{~ms}$ (point I) \\
\hline \multicolumn{2}{|l|}{ Quantum yields and probabilities } \\
\hline$\varphi \mathrm{P}_{0}=\mathrm{F}_{\mathrm{v}} / \mathrm{F}_{\mathrm{m}}=\mathrm{TR}_{0} / \mathrm{ABS}=\left(\mathrm{F}_{\mathrm{m}}-\mathrm{F}_{0}\right) / \mathrm{F}_{\mathrm{m}}=1-\left(\mathrm{F}_{0} / \mathrm{F}_{\mathrm{m}}\right)$ & Maximum quantum yield of primary photochemistry (at $t=0$ ) \\
\hline$\psi \mathrm{E}_{0}=\mathrm{ET}_{0} / \mathrm{TR}_{0}=1-\mathrm{V}_{\mathrm{J}}$ & $\begin{array}{l}\text { Probability (at } t=0 \text { ) that a trapped exciton moves an electron into the } \\
\text { electron transport chain beyond } \mathrm{Q}_{\mathrm{A}}^{-}\end{array}$ \\
\hline $\begin{array}{l}\varphi \mathrm{E}_{0}=\varphi \mathrm{P}_{0} \times \psi \mathrm{E}_{0}=\left(\mathrm{TR}_{0} / \mathrm{ABS}\right) \times\left(\mathrm{ET}_{0} / \mathrm{TR}_{0}\right)= \\
\mathrm{ET}_{0} / \mathrm{ABS}=\left(1-\mathrm{F}_{0} / \mathrm{F}_{\mathrm{m}}\right) \times\left(1-\mathrm{V}_{\mathrm{J}}\right)\end{array}$ & Quantum yield of electron transport (at $t=0$ ) \\
\hline \multirow{2}{*}{$\begin{array}{l}\left.\varphi \mathrm{D}_{0}=\mathrm{DI}_{0} / \mathrm{ABS}=1-\varphi \mathrm{P}_{0}=\mathrm{F}_{0} / \mathrm{F}_{\mathrm{m}}\right] \\
\delta \mathrm{R}_{0}=\mathrm{RE}_{0} / \mathrm{ET}_{0}=\left(1-\mathrm{V}_{\mathrm{I}}\right) /\left(1-\mathrm{V}_{\mathrm{J}}\right)\end{array}$} & Quantum yield of energy dissipation (at $t=0$ ) \\
\hline & $\begin{array}{l}\text { Efficiency/probability with which an electron from the intersystem electron } \\
\text { carriers moves to reduce end electron acceptors at the PSI acceptor side (RE) }\end{array}$ \\
\hline$\varphi \mathrm{R}_{0}=\mathrm{RE}_{0} / \mathrm{ABS}=\varphi \mathrm{P}_{0} \times \psi \mathrm{E}_{0} \times \delta \mathrm{R}_{0}$ & $\begin{array}{l}\text { Quantum yield of reduction of end electron acceptors at the PSI acceptor } \\
\text { side (RE) }\end{array}$ \\
\hline $\mathrm{RC} / \mathrm{ABS}=\left(\mathrm{RC} / \mathrm{TR}_{0}\right) \times\left(\mathrm{TR}_{0} / \mathrm{ABS}\right)=\left(\mathrm{V}_{\mathrm{J}} / \mathrm{M}_{0}\right) \times\left(\mathrm{F}_{\mathrm{v}} / \mathrm{F}_{\mathrm{m}}\right)$ & Total number of active reaction centers per absorption \\
\hline \multicolumn{2}{|l|}{ Specific energy fluxes } \\
\hline $\mathrm{ABS} / \mathrm{RC}=\mathrm{M}_{0} \times\left(1 / \mathrm{V}_{\mathrm{J}}\right) \times\left(1 / \varphi \mathrm{P}_{0}\right)$ & Absorption flux per reaction center $(\mathrm{RC})$ at $t=0$ \\
\hline $\mathrm{TR}_{0} / \mathrm{RC}=\mathrm{M}_{0} \times\left(1 / \mathrm{V}_{\mathrm{J}}\right)$ & Trapping flux (leading to $\mathrm{Q}_{\mathrm{A}}$ reduction) per $\mathrm{RC}$ at $t=0$ \\
\hline $\mathrm{ET}_{0} / \mathrm{RC}=\mathrm{M}_{0} \times\left(1 / \mathrm{V}_{\mathrm{J}}\right) \times \psi \mathrm{E}_{0}$ & Electron transport flux (further than $\mathrm{Q}_{\mathrm{A}}^{-}$) per $\mathrm{RC}$ at $t=0$ \\
\hline $\mathrm{DI}_{0} / \mathrm{RC}=(\mathrm{ABS} / \mathrm{RC})-\left(\mathrm{TR}_{0} / \mathrm{RC}\right)$ & Dissipated energy flux per RC at $t=0$ \\
\hline $\mathrm{RE}_{0} / \mathrm{RC}=\mathrm{M}_{0} \times\left(1 / \mathrm{V}_{\mathrm{J}}\right) \times \psi \mathrm{E}_{0} \times \delta \mathrm{R}_{0}$ & Reduction of end acceptors at PSI electron acceptor side per RC at $t=0$ \\
\hline \multicolumn{2}{|l|}{ Performance indices } \\
\hline $\mathrm{PI}_{(\mathrm{ABS})}=\mathrm{RC} / \mathrm{ABS} \times\left[\varphi \mathrm{P}_{0} /\left(1-\varphi \mathrm{P}_{0}\right)\right] \times\left[\psi \mathrm{E}_{0} /\left(1-\psi \mathrm{E}_{0}\right)\right]$ & Performance index based on absorption \\
\hline $\mathrm{PI}_{(\text {Total })}=\mathrm{PI}_{\mathrm{ABS}} \times\left[\delta \mathrm{R}_{0} /\left(1-\delta \mathrm{R}_{0}\right)\right]$ & $\begin{array}{l}\text { Overall performance index, which measures the performance up until the } \\
\text { final electron acceptors of PSI }\end{array}$ \\
\hline
\end{tabular}

(C) The authors. This is an open access article distributed under the terms of the Creative Commons BY-NC-ND Licence. 